Apart from the expedition to Sierra Leone men. tioned above, the only purely collecting trip which Austen made was in 1896, when he and the late F. O. Pickard Cambridge spent three months on the Amazon as naturalists on the cable ship Faraday. A greater opportunity for field work came to him during the Great War, when, after a period in France, in command of a company of the Artists' Rifles, he was transferred to the Egyptian Expeditionary Force for special duty in connexion with insect. born diseases. His work on mosquito and house. fly control earned him the D.S.O., and in spite of the arduous nature of this work he still found time and energy to make collections of other Diptera. Arrears of work, and later, official duties when he was appointed first deputy-keeper (1924) and then keeper (1927) of the Department of Entomology gave him little time for studying his Palestine collections. However, his retirement from the Museum staff in 1932 gave him more ample leisure and he turned with zest to the completion of a long-deferred labour of love and eventually (July 1937) produced a handsome volume on the Bombyliidæ of Palestine, which includes descriptions of the numerous species of this family collected by himself.

Austen's descriptive work, though sometimes criticized for a certain lack of conciseness in wording, embodied throughout three qualities upon which he always set a high value : accuracy, consistency and neatness. His neatness was exemplified in the wonderfully clear and firm handwriting, in which he took a just pride, and in the orderly arrangement of the collections under his charge. So precise indeed was this arrangement that visitors not infrequently remarked that the cabinet specimens were like well-trained regiments of soldiers on parade.

Although Austen's published work dealt almost exclusively with the groups of insects which were in his official charge, his interests were much wider. $\mathrm{He}$ preferred the Zoological Society to the Entomological Society on account of its wider outlook, and served on the publication committee of the former body. He was at one time vice-president of the Royal Society of Tropical Medicine and Hygiene, a member of the executive committees of the Imperial Institute of Entomology, the British Mosquito Control Institute, and the Society for the Preservation of the Fauna of the Empire. As a colleague he was loyal, purposeful, always anxious to increase the efficiency and prestige of his department, strongly resentful of injustice, and a strict disciplinarian. He was one of the small band to whom the present staff of the British Museum (Natural History) owes, almost entirely, the greatly improved conditions which the staff enjoys. Intensely patriotic, and with a very strong sense of the duty of a citizen, it is not surprising that he looked back with pride upon his service in the "C. I. V." and in the Great War, and that he took a keen and active interest in the local affairs of Northwood, where he had lived since 1913. Those who had the privilege of serving with him will always remember him, a man upright in body and mind, of sterling character, a manly man.
N. D. R. and F. W. E.

\section{Mr. J. L. Starkey}

ThE murder of Mr. J. L. Starkey, director of the Marston-Wellcome Archæological Expedition to the Near East, in Palestine on the evening of January 10, when he was on his way from his camp at Tell Duweir to Jerusalem to attend the opening ceremony of the new Palestine Archæological Museum on the following day, has deprived field archæology in the Near East of one of its most competent practitioners and exponents.

James Leslie Starkey was born on January 3, 1895, and received his training as a field archæologist under the British School of Archæology in Egypt. When in $1926 \mathrm{Sir}$ Flinders Petrie, owing to the restrictions imposed on archæological excavation in Egypt, transferred his activities to Palestine, Mr. Starkey accompanied him and became his right-hand man. A succession of operations on sites in the neighbourhood of Gaza brought to light important evidence bearing on the periods of the Egyptian occupation, the Hyksos and the early Bronze and Stone Ages of Palestine. More especially significant, perhaps, was the varied evidence which pointed to Palestine having been a centre or gathering point in international relations. This work led Starkey to the excavation of Tell Duweir.

The systematic excavation of Tell Duweir began in 1932. Mr. Starkey, convinced of the importance of this extensive site for Palestinian prehistory by the evidence of surface finds, and more especially by the abundance of potsherds it showed, approached Sir Charles Marston, for whom Prof. John Garstang was then excavating the site of Jericho, and persuaded him to undertake its investigation, at first in cooperation with Mr. H. D. Colt, and afterwards with Sir Henry Wellcome and Sir Robert Mond. The first season's systematic excavation went far to sub. stantiate, if indeed it did not quite fully confirm, his tentative conclusion that Tell Duweir, situated eighteen miles south-west of Jerusalem, rather than Tell el-Hesy, a site some ten miles away excavated many years before by Sir Flinders Petrie, was to be identified with the Biblical Lachish. The site was shown to have been in almost continuous occupation as a position of importance from the early Bronze Age down to the period of Persian occupation, while in the period of the Jewish kingdom when it was probably the centre of the defensive system of Palestine on this front, it had been sacked twice, inferentially by Sennacherib and Nebuchadnezzaron the second occasion burned. The identification with the Biblical Lachish was borne out later by the discovery here of the famous Lachish letters, the earliest known personal documents in Hebrew, and the earliest example of Hebrew writing. Even more important in the history of written records are the inscribed ewer and copper dagger, on which a primitive form of alphabetic script is held by experts to be closely akin to the Sinaitic script discovered by Sir Flinders Petrie, antedating considerably the earliest known Phœnician alphabetic scripts, which possibly may be derived from it.

This brief notice of Mr. Starkey's work cannot close without reference to one instance of his flair 
for the importance of a site, of which the full significance was not apparent until last year. This was his foresight in securing for the Marston-Wellcome Expedition the concession to excavate what has since come to be known as the "Bethlehem Bone Beds" (see Nature, 140, 431; 1937), in which have been found the fossil remains of numerous species previously unrecorded in Palestine, including the first specimen to be found in Palestine of the elephant and also of Hipparion, while fractured pebbles, found in 1937, but still sub judice, may turm out to be the first evidence of eolithic man in Palestine.

Mr. Starkey's interests were not confined to the past, and he had taken advantage of the opportunities afforded by the organization of his expedition to secure valuable photographic and other records of the people of Palestine of to-day. By the irony of circumstance, Mr. Starkey met his death at the hands of Arabs, although not only were his relations with his own Arab workmen of the most cordial character, but his scheme of excavation also made provision for ameliorating their condition by instituting cultivation plots on the site as the work proceeded.
WE regret to announce the following deaths :

Mr. W. H. B. Cameron, lecturer in physics in the University of Sheffield, known for his work in spectroscopy, on February 16, aged thirty-six years.

Dr. Ernest Goulding, formerly vice-principal of the Plant and Animal Products Department of the Imperial Institute, on February 15, aged sixty-eight years.

Prof. Gustav Jäger, emeritus professor of physics in the Technical High School, Vienna, on January 21, aged seventy-two years.

Prof. Anton Lampa, Privatdozent in physies in the University of Vienna, formerly professor in the German University, Prague, on January 26, aged seventy years.

Prof. H. E. Simpson, professor of geography and geology in the University of North Dakota, an authority on the geology of water supply, on January 31, aged sixty-three years.

Prof. H. W. Tyler, emeritus professor of mathematics in the Massachusetts Institute of Technology, secretary of the American Association of University Professors in 1916-33, on February 2, aged seventythree years.

\section{News and Views}

\section{Sir George Simpson, K.C.B., C.B.E., F.R.S.}

THE directorship of the Meteorological Office of the Air Ministry of Great Britain is one of the country's most important scientific posts and the recent announcement that Sir George Simpson will retire in September will arouse wide interest and regret. He has had heavy responsibilities. When he assumed office in 1920, his first task was to weld into a coherent whole the very heterogeneous material that the Great War had left behind it, in such a way as to supply the needs of civil aviation, the Navy, the Army and the Air Force, as well as the general public. He shortly had to provide the information demanded by the ill-fated airship programme which came to an end with the $R 101$ disaster: this involved a thorough investigation of air motion for use in airship construction and mooring, and an organization for providing route reports for airships in flight such as that which made possible the transatlantic flights of $R 100$. Latterly, there has been the organization occasioned by the Air Force expansion and the air mail scheme: accordingly, there is now a section for synoptic work over the North Atlantic and another to give information for the flying boats to South Africa and the East during the first stages of their journeys. Happily, in meteorology, international co-operation is a vital necessity, involving a highly complex arrangement of codes for distributing weather data over the earth; here the British representative has played a very important part. With a fine record of scientific research, both experi- mental and theoretical, Sir George has shown that, as has often been urged in these pages, executive ability is not confined to those with a literary, political or other training. $\mathrm{He}$ is admirable in discussing a purely technical theme; but he is equally impressive in fighting a difficult case through a committee when ingenuity, tact and business capacity have full play; and his success would have been impossible without his obvious courage and sincerity.

\section{Mr. N. K. Johnson}

Mr. N. K. Johnson of the Chemical Defence Research Department has been appointed to succeed Sir George Simpson. Mr. Johnson received his scientific training at the Imperial College of Science and Technology, South Kensington, choosing physics as the main subject for his honours degree. After a period of post-graduate work in astrophysics under Prof. A. Fowler, he went in 1913 to the Hill Observatory, Sidmouth, as assistant to Sir Norman Lockyer and Dr. W. J. S. Lockyer. Relinquishing this post, he served during the Great War in the Royal Air Force, and on the conclusion of hostilities was appointed professional assistant in the Meteorological Office. After a period of service at Shoeburyness, Mr. Johnson was seconded for duty under the War Office at the Experimental Station, Porton. Here he found full scope for his natural inclination towards experimental research work and he tackled with great success the new and difficult meteorological problems associated with chemical warfare. During this 